\title{
1420 Ma diabasic intrusives from the Mesoproterozoic Singhora Group, Chhattisgarh Supergroup, India: Implications towards non-plume intrusive activity
}

\author{
Priyabrata Das ${ }^{1}$, Kaushik Das ${ }^{1, *}$, Partha Pratim Chakraborty ${ }^{2, * *}$ and S Balakrishnan $^{3}$ \\ ${ }^{1}$ Department of Geology, Bengal Engineering and Science University, Howrah 711 103, India. \\ ${ }^{2}$ Department of Geology, University of Delhi, Delhi 110 00\%, India. \\ ${ }^{3}$ Department of Earth Sciences, Pondicherry University, Pondicherry, India. \\ *e-mail: kaushik.met@gmail.com \\ **e-mail: parthageology@gmail.com
}

\begin{abstract}
Besides offering significant clues towards tracking the geochemical evolution of the mantle and architectural reconstruction of different 'supercontinent', geochronological and geochemical appraisal of igneous inputs are also important to bracket the depositional time frame of any lithopackage, particularly, the unfossiliferous sedimentary successions. The present study deals with diabasic intrusive within Mesoproterozoic Saraipalli Formation, which is an argillaceous constituent present at the basal part of nearly $400 \mathrm{~m}$ thick four-tiered unmetamorphosed but deformed sedimentary succession of Singhora Group, Chhattisgarh Supergroup, central India. The SE-NW trending intrusive comprises mainly of plagioclase and augite together with minor orthopyroxene, biotite and opaque minerals. Though some plagioclase laths are partially sericitized, the ophitic-to-subophitic texture of the rock is well preserved. Major and trace element geochemical data indicate that this intrusive is basalt-to-basaltic andesite in character and of subalkaline basalt affinity. Multi-element plot shows overall LILE-enrichment and enrichment of $\mathrm{Pb}$ and slight depletion of $\mathrm{Nb}$ and $\mathrm{P}$, coupled with moderate $\mathrm{La} / \mathrm{Nb}$ and $\mathrm{Th} / \mathrm{Nb}$ ratios. $\mathrm{Zr}, \mathrm{Y}$ and $\mathrm{Nb}$ ternary diagrams plot in the fields of within plate basalt. Selected HFSE ratios indicate a non-plume source with crustal assimilation/sediment mixing. Sm-Nd and $\mathrm{Rb}-\mathrm{Sr}$ isotope data show that the intrusive has $\mathrm{Sr}_{\text {initial }}$ and $\mathrm{Nd}_{\text {initial }}$ of $0.709377-0.706672$ and $0.510919-0.510815$, respectively. Positive $\varepsilon^{t} \mathrm{Nd}[t=1420 \mathrm{Ma}]$ values $(+0.3$ to +2.3$)$ indicate depleted isotopic nature of their protolith. The calculated $T_{\mathrm{DM}}$ age is 1.7-1.9 Ga. The mineral-whole rock isochron data $(\mathrm{Sm}-\mathrm{Nd}$ systematics) of the intrusive implies an emplacement age of ca. 1420 Ma. Considering synchronous terrain boundary shear zone development in Bastar craton on the southeastern part of the Singhora basin, mafic magmatism in Eastern Ghats and large-scale basic intrusion in Sausar mobile belt, a major tectono-thermal event around $1400 \mathrm{Ma}$ is surmised that affected eastern Indian craton. Moreover, geochronology of a bedded porcellanite unit (ca. $1500 \mathrm{Ma}$ ) at the base and a discordant basic intrusive (ca. $1420 \mathrm{Ma}$ ) allowed a unique opportunity to qualitatively offer an upper bound of time bracket for the deposition of Saraipalli Formation, i.e., 80 Ma.
\end{abstract}

\section{Introduction}

The Proterozoic era (2500-543 Ma) represents nearly one-third of the Earth history and records most dramatic changes in the evolution of the Earth that includes accretion and dispersal of supercontinents, viz., Columbia (Rogers and Santosh 2002; Zhao et al 2004) and Rodinia

Keywords. Chhattisgarh Supergroup; Singhora Group; diabasic intrusive; geochemistry and age. 
(Dalziel 1991; Moores 1991; Hoffman et al 1998). The reconstruction of those 'supercontinent' architectures demand understanding of timing and processes behind microcontinent docking, stabilization of crust and evolution of marginal mobile belts in a concerted manner involving all coexistent tectonogeomorphic crustal subdivisions, viz., craton, craton-hosted sedimentary basins and adjoining orogenic belts. This is necessary to understand the mutual interaction between the endogenic and exogenic processes operative in course of building or break-up of supercontinent at any concerned time period. The Bastar carton, Mesoproterozoic Chhattisgarh basin and its adjoining basins, viz., Khariar, Ampani, etc., often sharing common boundary with the Eastern Ghats granulite belt (EGB) can be an ideal candidate to study. This may help in better understanding towards the role of different crustal blocks of central to eastern India in the amalgamation and break-up history of Proterozoic supercontinents.

Bastar craton, Eastern Ghats granulite belt and Chhattisgarh basin - all the three crustal subdivisions in central India have been studied independently by previous researchers focusing the possible age of cratonization, geochemical affinity of the rock suites, tectonothermal evolution of the orogenic belt and depositional history of the sediments (Karmakar et al 2009; Srivastava and Gautam 2009; Chakraborty et al 2010 and the references therein). The recently generated geochronological data (Patranabis-Deb et al 2007; Bose et al 2008; French et al 2008; Das et al 2009; Ratre et al 2010), allowed us to visualize that the three subdivisions shared the same time frame (Meso-to-Neoproterozoic time) in course of their respective evolution. To further strengthen the idea, it is important to generate more tightly constrained geochronological data, in particular from the lithodemic units present within all the three crustal subdivisions. Compared with the available database on the volcanic inputs within the craton and mobile belt, those present within the sedimentary covers are scantily attended and await studies in terms of geochemistry and geochronology. Indeed, such geochemical and geochronological appreciation of the magmatic inputs (either in the form of dykes or as conformable lithodemic units) present within the Chhattisgarh and its adjoining basins will have multifold implications, viz.,

- identification of isochronous markers may help in correlating the lithotectonic domains in regional and global perspective,

- the spatio-temporal evolution of magma chamber(s) taking into consideration the secular chemical variation in the mantle source, and
- the exhumation-erosional episodes of the orogenic hinterland and its cause-effect relationship, if any, with the coeval events in adjacent craton.

During Proterozoic time, growth of the continents took place by the addition of mantle-derived material to pre-existing continental blocks. Majority of such material addition was associated with continental crustal growth under different tectonic environments like, accretionary orogens, collisional orogens and within supercontinents undergoing rifting and break-up (Windley Brian 1995). Major and trace element signatures in each case are unique and show the chemical character of the prevailing mantle sources.

The Precambrian basin successions of peninsular India experienced different magmatic activities at different stratigraphic levels in the form of basic sills and flows, felsic lavas, ignimbrites, pyroclastic flow and fall deposits, dolerite and kimberlite dykes, and granite plutons that has been recently reviewed by Chakraborty et al (2010) (their table 3 and references therein). Reports of magmatic activity are available in literature from Chhattisgarh and its satellite basins. Das et al (2001) reported volcanic activity in the form of pyroclastic, tuffaceous (including porcellanite) rocks and basic intrusives in the Singhora basin, kimberlites cutting across the Khariar sediment succession, hornblende granodiorite intrusion in the Ampani succession and ultramafics from Indravati succession among others. However, very little data are available on these magmatic inputs, except for their broad lithological description. It is also interesting to note the presence of dyke swarms at the interface of Chhattisgarh main basin and adjacent craton (Das et al 1992; Srivastava and Gautam 2009).

In the present study, we have petrographically and geochemically (including major, trace and rare-earth elements) characterized one of the basic intrusives in the Singhora Group, the basal package of Chhattisgarh Supergroup. Rb-Sr and Sm$\mathrm{Nd}$ isotopic studies on minerals and whole rock are used to constrain the age of the intrusive and its source.

\section{Geological background and field relation of the studied intrusive unit}

Chhattisgarh Supergroup, the second largest Proterozoic succession in peninsular India, is constituted of $\sim 2300 \mathrm{~m}$ thick succession of mixed siliciclastic-carbonate strata that unconformably overlie the gneissic basement of Bhandara craton and is classified into three groups, Singhora Group, Chandarpur Group and Raipur Group 
(figures 1 and 2). The Singhora Group and Chandarpur Group are essentially siliciclastic and the Raipur Group is dominated by carbonate and shale with coarser siliciclastics occurring only at a few stratigraphic intervals (Murti 1987; Das et al 1992; Patranabis-Deb and Chaudhuri 2007). The variably deformed Singhora Group of rocks occupies the lowermost stratigraphic interval and presents angular unconformable relationship with the near horizontal strata of immediately overlying Chandarpur Group of rocks (Chakraborty et al 2009). With $\sim 400 \mathrm{~m}$ thickness, the Singhora Group of rocks are exposed over $200 \mathrm{~km}^{2}$ outcrop area and stratigraphically subdivided into four formations, viz., Rehtikhol, Saraipalli, Bhalukona and Chuipalli, in order of superposition (figure 2). In contrast to the arenaceous character of Rehtikhol and Bhalukona Formations, the Saraipalli and Chuipalli Formations are essentially argillaceous, occasionally calcareous. Recent geochronologic date, i.e., $\sim 1.5 \mathrm{Ga}$ (Das et al 2009) from the monazite grains embedded within a bedded tuffaceous unit, present at the boundary between the
Rehtikhol and Saraipalli Formations, has strongly established the Mesoproterozoic time frame for the Singhora Group.

The beds in Rehatikhol Formation have northsouth strike and gentle dip $\left(8-10^{\circ}\right)$ towards west. In contrast, the heterolithic sandstone-shaleporcellanitic Saraipalli Formation exposes mesoscopic folds in the outcrop scale. Doubly plunging folds in the porcellanitic tuff-shale intercalations of Saraipalli Formation are very prominent in the northern and central parts of the basin. The fold axes are parallel to the trace of the lithoboundary and plunges at a moderate angle $\left(22^{\circ}-\right.$ $31^{\circ}$ ) either towards the north or to the south that leads to dome-basin fold interference geometry on a regional scale in Saraipalli Formation. Regional scale folding can also be noticed within the overlying Bhalukona Formation.

The diabasic intrusive, concern of the present study, occurs in the northern part of the Singhora

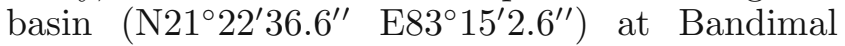
village (figure 1). The intrusive has an exposed length of nearly $455 \mathrm{~m}$ and width of $200 \mathrm{~m}$ at

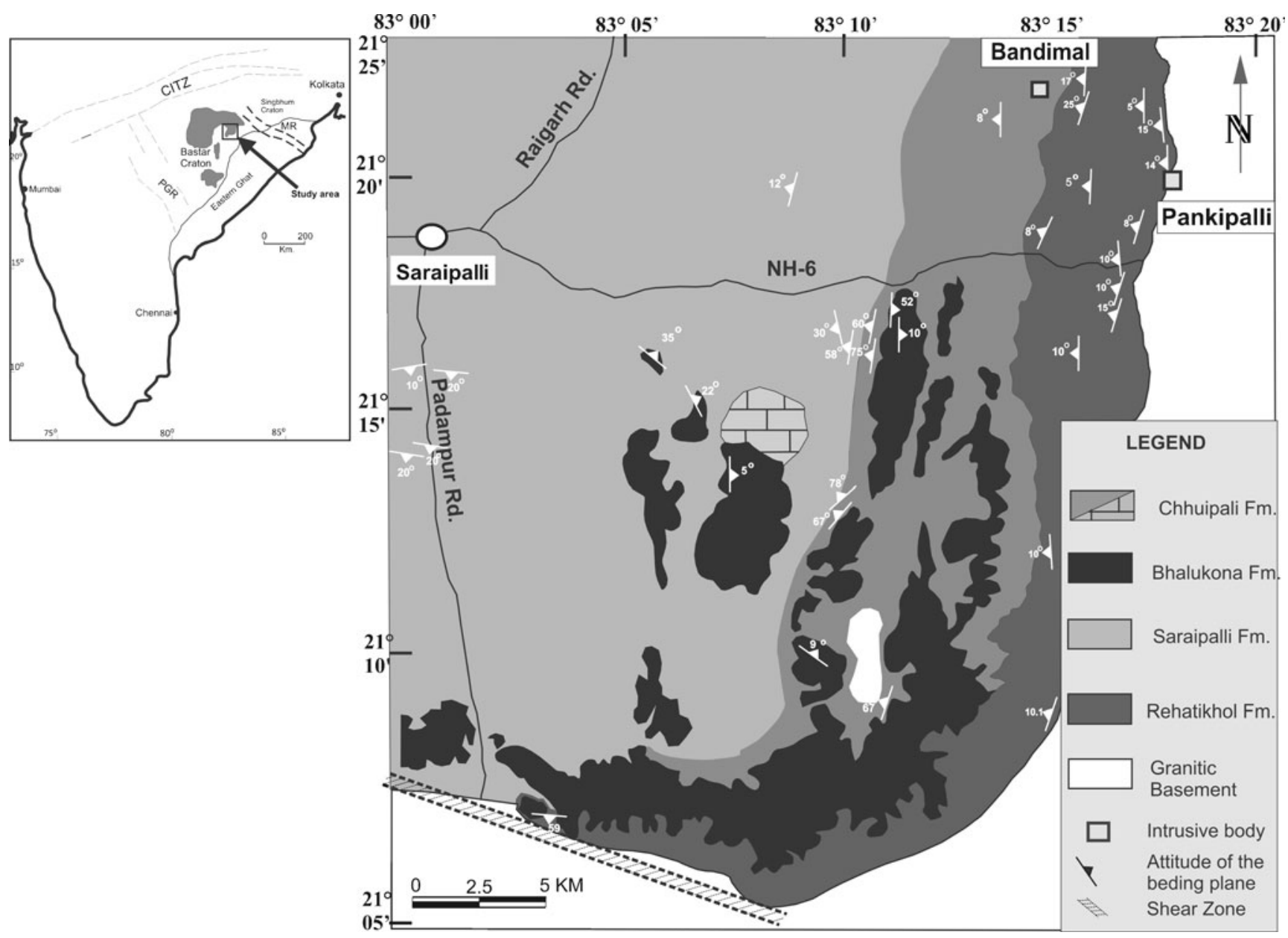

Figure 1. Map showing the position of Chhattisgarh basin and the surrounding tectonomorphic units of eastern India. Singhora basin is shown in square which is magnified on the right-hand side with detailed lithological disposition. The occurrences of the diabasic intrusives are shown at Bandimal and Pankipalli in the northern part of the mapped area. 


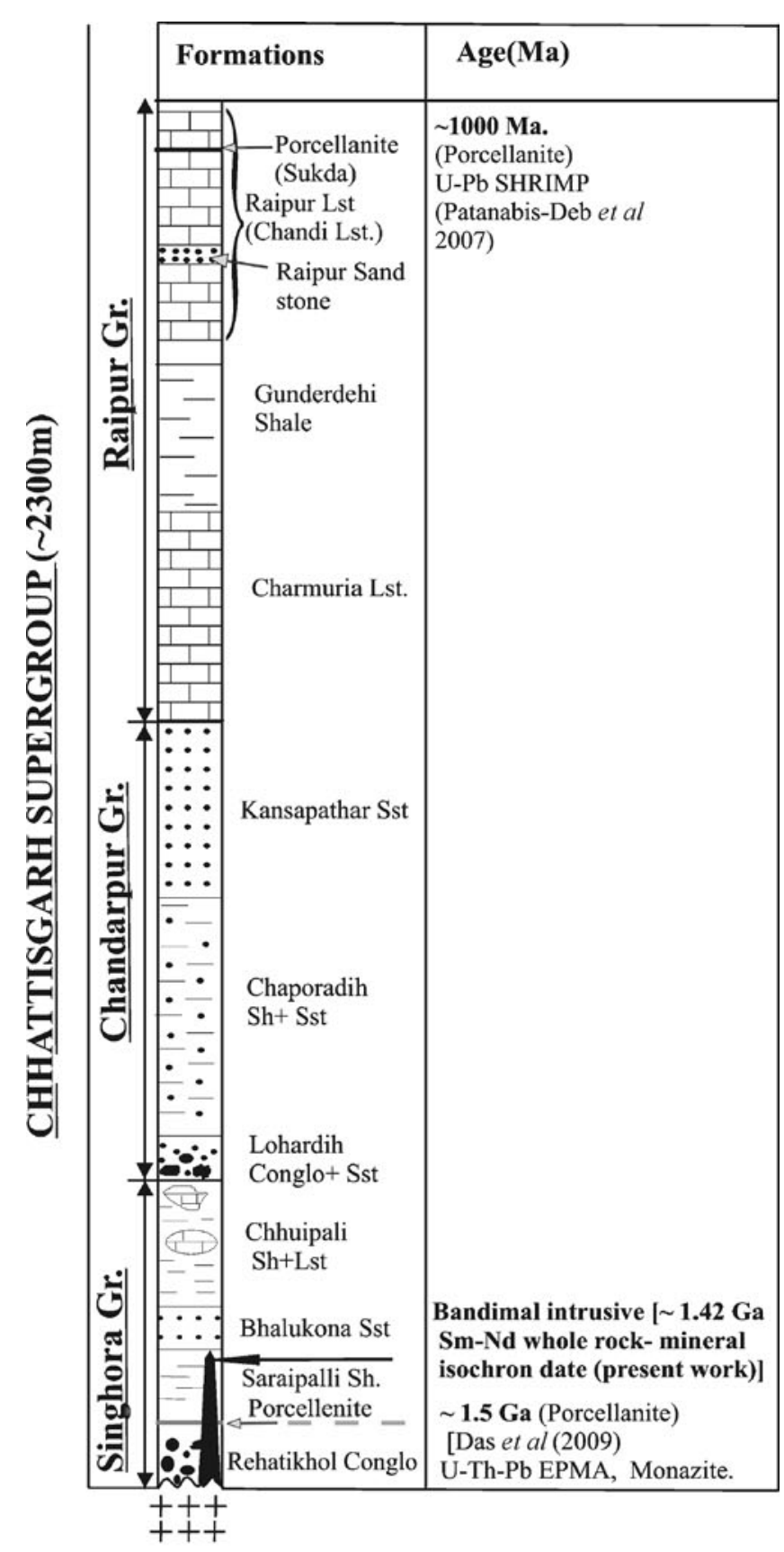

\section{LEGEND}

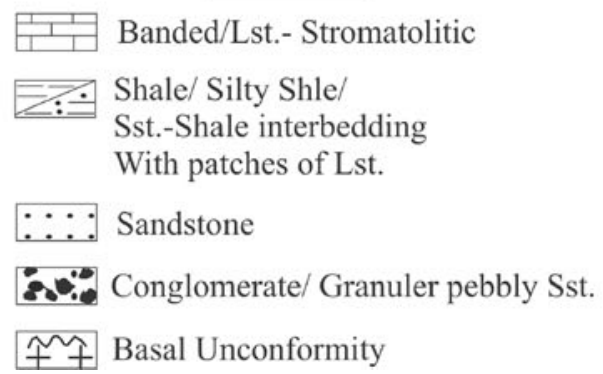

Figure 2. Stratigraphic sequence of Chhattisgarh Supergroup with the lower Singhora Group. The reported age data has also been shown. the maximum. The trend of this discordant diabasic intrusive is southeast (SE)-northwest (NW) $\left(120^{\circ}-300^{\circ}\right)$, at high angle with the strike of the adjacent sedimentary beds (strike $20^{\circ}$, dipping $15^{\circ}$ towards west). The intrusive is observed to cut across the heterolothic sandstone-shale units of Saraipalli Formation and is found in body contact with the shale interbeds (figure 3 ). A similarly oriented diabasic unit, but much smaller in size has also been found further east near Pankipalli village (N21 $\left.22^{\prime} 45.60^{\prime \prime} \mathrm{E} 82^{\circ} 57^{\prime} 43.6^{\prime \prime}\right)$ that cuts across the boundary between gneissic rocks of the craton and the Rehtikhol Formation. The field relation, however, implies that the studied unit is not traceable further down-dip of Saraipalli Formation. Hence, we interpret this unit as a discordant body at least till Saraipalli Formation and prefer to term it as an intrusive body. In the absence of any conclusive field data on the present erosional surface, it is difficult to term it either as a dyke or a sill.

\section{Methodology}

The intrusive units were studied for their petrography, mineral chemistry, bulk geochemistry including major, trace element and REE, isotope geochemistry and geochronology. Chemical compositions of minerals from representative samples were analyzed using Cameca SX 100 Electron Probe Micro Analyzer (EPMA) at the Wadia Institute of Himalayan Geology (WIHG) Dehradun, India. The EPMA was operated at $15 \mathrm{kV}$ acceleration voltage using $15 \mathrm{nA}$ of specimen current. Probe diameter of $1-2 \mu \mathrm{m}$ for the spot size was used for point analyses. Natural standards were used and raw data were corrected by PAP program.

Bulk chemistry for the samples was analyzed by XRF (major and trace elements) using fused bead in Panalytical MagixPro machine at Hokkaido University, Japan. Rare earth element (REE) was measured by ICP-MS (Perkin-Elmer) at WIHG, with $0.04 \mathrm{gm}$ of the sample subjected to standard acid digestion with $\mathrm{HF}-\mathrm{HNO}_{3}$. The standard acid treatment was repeated until a clear solution was obtained. The clear solution was then treated with $1 \mathrm{~N}$ HNO3, and a 100-mL solution was taken for analysis. The accuracy and precision were $5-10 \%$ for REEs. For major oxides and trace elements, internal standard (HB1, basalt from Rishiri volcano, Japan) was measured before and after the analysis of unknown samples. The average values and the reported values are given in table 1 to show the precision and accuracy.

Further, the petrographically and geochemically studied samples are analyzed for determination of $\mathrm{Rb}-\mathrm{Sr}$ and $\mathrm{Sm}-\mathrm{Nd}$ isotope using 


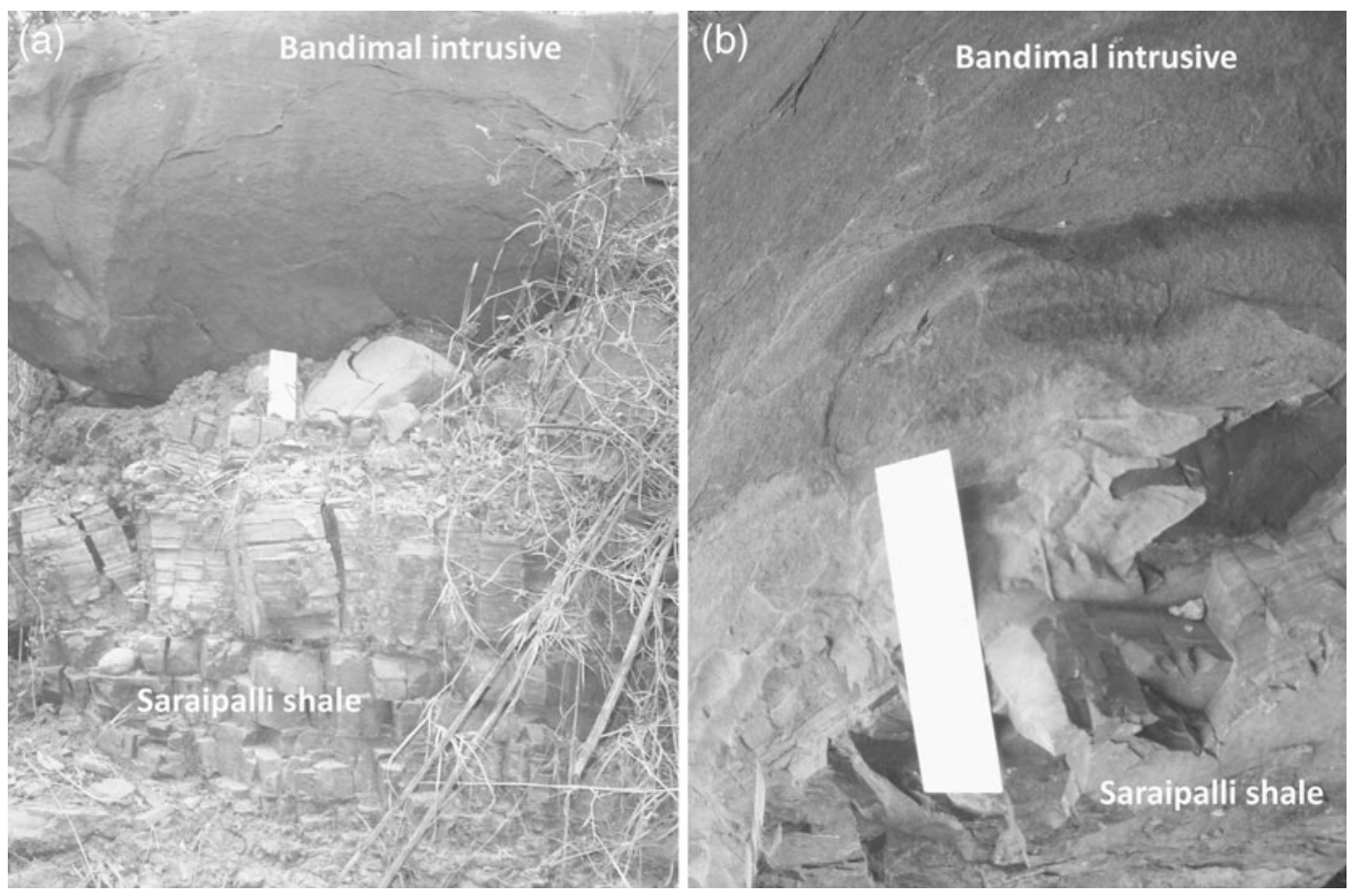

Figure 3. Field photograph showing (a) contact relationship between the diabasic intrusive body and the Saraipalli shale and (b) a closer view to note that there is not much contact effect. The scales (white) in both the figures are of $15 \mathrm{~cm}$ in length.

Thermal Ionization Mass Spectrometer (Triton, Thermo-Finnigan), in the National Facility for Isotope Geosciences, Department of Earth Sciences, Pondicherry University, India. Two samples, one from Bandimal unit and one from Pankipalli unit have been analyzed. All the samples are analyzed twice. The sample pieces are crushed and pulverized using hardened steel and agate mortar, respectively. Pyroxene and plagioclase feldspar were separated from whole rock powdered sample of Bandimal unit using bromoform and Frantz magnetic separator. Pure pyroxene and plagioclase mineral fractions were obtained by picking them under a binocular microscope. The whole-rock and mineral samples are weighed precisely and taken in a pre-weighed Savillex ${ }^{\circledR}$ beaker. About 1-2 ml of mixture containing hydrofluoric acid $(\mathrm{HF})+1 \mathrm{ml}$ $\mathrm{HNO}_{3}+$ few drops of $\mathrm{HCl}$ are added to the sample beaker. The beaker was kept on a hot plate at $120^{\circ} \mathrm{C}$ overnight for digestion, followed by standard chemical separation procedures for each of the isotopic system as detailed in Anand and Balakrishnan (2010). Once separated, the elements in each isotopic system are loaded by standard procedures onto pre-conditioned Re filament used in the solid source thermal ionization mass spectrometer (TIMS). AMES Nd standard analyzed nine times during the course of this study yielded mean ${ }^{143} \mathrm{Nd} /{ }^{144} \mathrm{Nd}$ ratio of $0.511968 \pm 2$, and SRM-987 yielded a mean ${ }^{87} \mathrm{Sr} /{ }^{86} \mathrm{Sr}$ ratio of $0.710272 \pm 4$. As the mean ${ }^{87} \mathrm{Sr} /{ }^{86} \mathrm{Sr}$ ratio on $\mathrm{SRM}$ is $30 \mathrm{ppm}$ higher than the reported value, the data on samples are corrected by this value.

\section{Petrography and mineral chemistry}

Thin section study of samples collected from the mafic intrusive bodies reveals moderately phyric character with plagioclase and pyroxene as the major phases. Most of the plagioclase grains are $40-50 \mu \mathrm{m}$ in width and less than $70-80 \mu \mathrm{m}$ in length. Rarely, plagioclase laths longer than $150 \mu \mathrm{m}$ are observed. The clinopyroxene grains, in general, are less than $50 \mu \mathrm{m}$ in size and occasionally form aggregates of smaller grains. Such size distribution of major minerals imparts medium-tofine grained character for the studied rock samples. There is no systematic variation of grain size or modal abundances of the minerals in the studied diabasic units. In terms of grain shape, plagioclase and pyroxene grains are euhedral-tosubhedral with presence of distinct grain boundary. Differently oriented plagioclase laths enclose clusters of pyroxene grain showing intergranural texture (figure 4). Plagioclase and clinopyroxene grains often exhibit ophitic-to-subophitic texture. Lath-shaped plagioclases are rarely zoned. Besides, there are magnetite-ilmenite and sphene with minor calcite, biotite and glass. Occurrence of calcite is local even in microscopic scale and principally confined within the micro-fractures 
Table 1. Representative bulk rock analysis of the intrusive and their calculated CIPW norms on the right hand side.

\begin{tabular}{|c|c|c|c|c|c|c|}
\hline & $10 / \mathrm{L} 7$ & $7 / 21$ & $10 / \mathrm{L} 7 \mathrm{~b}$ & 7/21_2 & $7 / 25$ & $\mathrm{HB} 1 *$ standard \\
\hline $\mathrm{SiO}_{2}$ & 53.489 & 52.225 & 52.886 & 52.312 & 50.109 & $50.30(50.187)$ \\
\hline $\mathrm{TiO}_{2}$ & 2.07 & 2.032 & 2.12 & 2.108 & 1.67 & $1.02(1.024)$ \\
\hline $\mathrm{Al}_{2} \mathrm{O}_{3}$ & 16.111 & 16.11 & 15.99 & 16.14 & 14.991 & $16.60(16.556)$ \\
\hline $\mathrm{Fe}_{2} \mathrm{O}_{3}$ & 12.159 & 12.277 & 12.289 & 12.235 & 13.971 & $10.56(10.497)$ \\
\hline $\mathrm{MnO}$ & 0.157 & 0.159 & 0.154 & 0.162 & 0.27 & $0.17(0.172)$ \\
\hline $\mathrm{MgO}$ & 4.635 & 5.096 & 4.596 & 4.935 & 6.055 & $8.73(8.726)$ \\
\hline $\mathrm{CaO}$ & 7.563 & 6.92 & 7.58 & 6.98 & 7.319 & $9.28(9.279)$ \\
\hline $\mathrm{Na}_{2} \mathrm{O}$ & 3.326 & 3.423 & 3.318 & 3.385 & 2.82 & $3.13(3.182)$ \\
\hline $\mathrm{K}_{2} \mathrm{O}$ & 0.714 & 0.892 & 0.702 & 0.884 & 1.74 & $0.73(0.730)$ \\
\hline $\mathrm{P}_{2} \mathrm{O}_{5}$ & 0.358 & 0.336 & 0.355 & 0.328 & 0.264 & $0.26(0.254)$ \\
\hline Total & 100.582 & 99.47 & 99.99 & 99.469 & 99.209 & $100.77(100.606)$ \\
\hline LOI & 2.64 & 2.59 & 2.61 & 2.56 & 2.37 & \\
\hline $\mathrm{Ba}$ & 600.536 & 747.738 & 641.445 & 742.8 & 893.966 & $188.748(193.566)$ \\
\hline $\mathrm{Rb}$ & 22.382 & 32.792 & 22.105 & 30.126 & 47.1 & $19.688(19.154)$ \\
\hline $\mathrm{Sr}$ & 435.73 & 422.949 & 432.29 & 420.824 & 290.742 & $382.356(375.954)$ \\
\hline $\mathrm{Zr}$ & 248.268 & 233.386 & 247.683 & 235.468 & 129.56 & $104.842(103.634)$ \\
\hline $\mathrm{Nb}$ & 17.935 & 17.355 & 17.857 & 17.297 & 19.643 & $5.154(5.207)$ \\
\hline $\mathrm{Ni}$ & 38.613 & 46.631 & 39.718 & 47.215 & 46.327 & $168.778(168.128)$ \\
\hline $\mathrm{Co}$ & 45.962 & 56.831 & 46.287 & 55.836 & 55.269 & $42.688(43.541)$ \\
\hline $\mathrm{Zn}$ & 111.901 & 111.453 & 110.826 & 110.58 & 97.862 & $79.512(77.196)$ \\
\hline $\mathrm{Cr}$ & 21.987 & 14.793 & 20.84 & 13.896 & 59.371 & $310.621(306.529)$ \\
\hline $\mathrm{La}$ & 32.16 & 29.61 & 23.809 & 28.371 & 23.65 & - \\
\hline $\mathrm{Ce}$ & 64.95 & 60.01 & 55.379 & 59.65 & 49.75 & - \\
\hline $\operatorname{Pr}$ & 8.13 & 7.53 & 7.56 & 7.56 & 6.43 & - \\
\hline $\mathrm{Nd}$ & 32.39 & 30.66 & 31.57 & 30.68 & 25.62 & - \\
\hline $\mathrm{Sm}$ & 6.8 & 6.63 & 6.5 & 6.35 & 5.34 & - \\
\hline $\mathrm{Eu}$ & 2.29 & 2.27 & 2.24 & 2.26 & 2.1 & - \\
\hline Gd & 7.19 & 6.88 & 7.05 & 6.92 & 5.66 & - \\
\hline $\mathrm{Tb}$ & 1.01 & 0.99 & 1.05 & 1.02 & 0.84 & - \\
\hline Dy & 5.37 & 5.44 & 5.41 & 5.41 & 4.75 & - \\
\hline Ho & 1.08 & 1.06 & 1.04 & 1.03 & 0.99 & - \\
\hline Er & 2.76 & 2.66 & 2.65 & 2.7 & 2.57 & - \\
\hline $\operatorname{Tm}$ & 0.39 & 0.38 & 0.36 & 0.37 & 0.38 & - \\
\hline $\mathrm{Yb}$ & 2.51 & 2.44 & 2.49 & 2.46 & 2.47 & - \\
\hline $\mathrm{Lu}$ & 0.38 & 0.37 & 0.37 & 0.35 & 0.38 & - \\
\hline $\mathrm{Y}$ & 30.096 & 29.434 & 30.102 & 29.681 & 26.055 & $25.026(25.080)$ \\
\hline $\mathrm{Sc}$ & 22.485 & 22.04 & 20.528 & 21.657 & 41.221 & $31.557(30.936)$ \\
\hline $\mathrm{V}$ & 155.374 & 161.07 & 152.684 & 160.524 & 272.981 & $211.658(210.598)$ \\
\hline $\mathrm{Cu}$ & 30.5 & 33.199 & 30.1 & 32.098 & 126.443 & $65.023(62.146)$ \\
\hline $\mathrm{Pb}$ & 14.125 & 11.206 & 14.06 & 11.134 & 7.314 & $3.514(3.524)$ \\
\hline Th & 6.173 & 5.268 & 5.983 & 5.161 & 3.465 & $3.779(3.977)$ \\
\hline $\mathrm{Ga}$ & 22.374 & 22.049 & 21.481 & 21.756 & 14.798 & $14.864(15.462)$ \\
\hline $\mathrm{Q}$ & 11.09 & 8.76 & 10.67 & 9.20 & 5.56 & \\
\hline Or & 4.22 & 5.27 & 4.15 & 5.22 & 10.28 & \\
\hline $\mathrm{Ab}$ & 28.14 & 28.96 & 28.08 & 28.64 & 23.86 & \\
\hline An & 26.92 & 25.96 & 26.66 & 26.23 & 23.11 & \\
\hline Di & 1.30 & 0.00 & 1.43 & 0.00 & 5.23 & \\
\hline Нy & 10.94 & 12.69 & 10.78 & 12.29 & 12.66 & \\
\hline Ilm & 0.34 & 0.34 & 0.33 & 0.35 & 0.58 & \\
\hline $\mathrm{Hm}$ & 12.16 & 12.28 & 12.29 & 12.24 & 13.97 & \\
\hline Tn & 4.65 & 4.35 & 4.78 & 4.41 & 3.35 & \\
\hline $\mathrm{Ru}$ & 0.00 & 0.08 & 0.00 & 0.13 & 0.00 & \\
\hline Ap & 0.85 & 0.80 & 0.84 & 0.78 & 0.63 & \\
\hline
\end{tabular}

*HB1 is basalt from Rishiri volcanic and used as the internal standard. Average values of standard before and after the unknown analyses are given. Values in parenthesis indicate the reported value of HB1. 


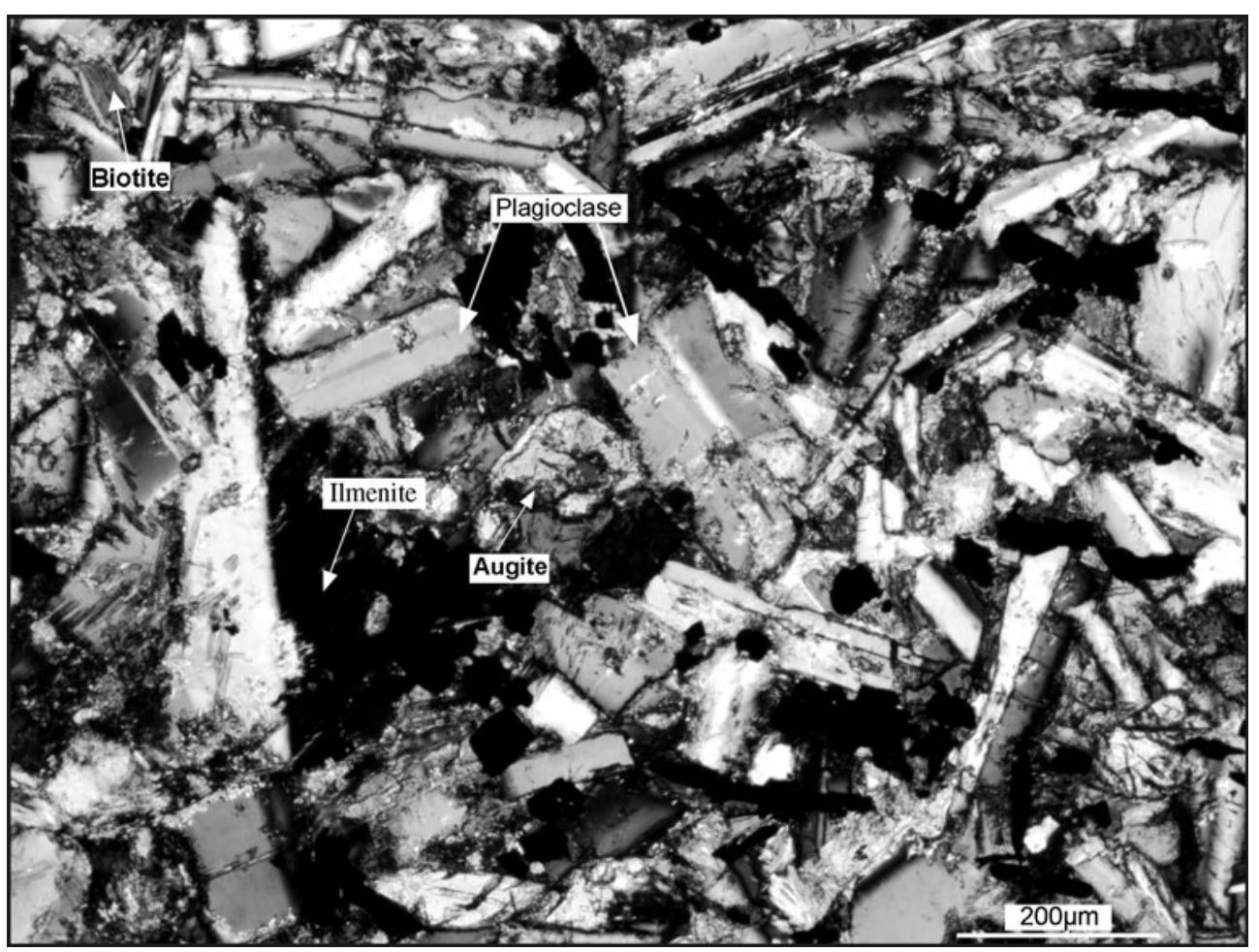

Figure 4. Photomicrograph of the diabasic intrusive. Note the preservation of magmatic textures and mineralogy defined dominantly by plagioclase laths, pyroxene and opaque minerals.

Table 2. Representative mineral compositions of pyroxene, plagioclase and ilmenite of the studied rock. Compositional values are recalculated from raw electron microprobe analysis data.

\begin{tabular}{lcccccc}
\hline Pyroxene $X_{\mathrm{Mg}}$ & 0.57 & 0.56 & 0.55 & 0.61 & 0.62 & 0.65 \\
Wo (mole\%) & 46.34 & 45.3 & 43.04 & 42.19 & 42.77 & 43.96 \\
En (mole\%) & 30.77 & 30.46 & 31.56 & 35.16 & 35.52 & 36.52 \\
Fs (mole\%) & 22.89 & 24.24 & 25.4 & 22.65 & 21.7 & 19.52 \\
Plagioclase & & & & & & \\
Ab (mole\%) & 41.82 & 42.34 & 45.24 & & & \\
An (mole\%) & 56.73 & 56.34 & 53.56 & & & \\
Or (mole\%) & 1.45 & 1.32 & 1.2 & & & \\
Ilmenite & & & & & & \\
Ilm (mole\%) & 73.57 & 89.52 & 19.45 & & & \\
Hm (mole\%) & 26.43 & 10.48 & 80.55 & & & \\
\hline
\end{tabular}

suggesting its secondary origin. Despite local sericitization the plagioclase grains are mostly fresh and often show well preserved twin lamellae. The rock unit is overall fresh except along the joint and fracture planes where pervasive alteration of the rock unit is noticed.

Chemical compositions (table 2) of the plagioclase phenocrysts are almost uniform and they are labradoritic $\left(\mathrm{Ab}_{41-45}, \mathrm{An}_{53-56}\right.$ and $\left.\mathrm{Or}_{1.2-1.4}\right)$ in composition. There is not much profound chemical zoning present in plagioclase grains. However, in some grains the core is slightly anorthite-rich in comparison to the rim. Subhedral clinopyroxene grains are not zoned, relatively less altered and compositionally augitic in nature $\left(\mathrm{Wo}_{42-46}, \mathrm{En}_{30-36}, \mathrm{Fs}_{19-25}\right.$ and $\left.\mathrm{X}_{\mathrm{Mg}}=0.57-0.65\right)$. Opaque minerals are mostly $\mathrm{Fe}-\mathrm{Ti}$ oxides and composition recalculation on 3-oxygen basis indicates a solid solution between ilmenite and hematite $\left(\mathrm{Ilm}_{19-73}\right.$ and $\left.\mathrm{Hm}_{80-10}\right)$.

\section{Geochemical and $\mathrm{Sr}-\mathrm{Nd}$ isotope characteristics}

Samples with least alteration effects were selected for geochemical analysis. The studied samples of the intrusive display small variation in major oxide compositions. This is a quartz-normative basalt with $\mathrm{SiO}_{2}=50-53$ wt\%, total alkalis $\left(\mathrm{Na}_{2} \mathrm{O}+\right.$ $\left.\mathrm{K}_{2} \mathrm{O}\right)$ of 4 wt\% with $\mathrm{K}_{2} \mathrm{O} / \mathrm{Na}_{2} \mathrm{O}$ of $0.21-0.26$ (table 1$). \mathrm{Mg} \#(42-46)$ is moderately low and $\mathrm{Cr}, \mathrm{Ni}$ contents vary between $13-21 \mathrm{ppm}$ and $38^{-}$ $47 \mathrm{ppm}$, respectively. Classification was done on the basis of bivariate and multivariate plots using the major and trace elements (figures 5 and 6 ). On the basis of major oxides abundance, the intrusive is categorized as basaltic andesite to basalt and plots on the boundary between tholeiite and calcalkaline series (figure $5 \mathrm{a}-\mathrm{c}$ ). Some selective trace elements of the studied samples show alkali basalt to subalkaline basalt nature in $\mathrm{Zr} / \mathrm{TiO}_{2}$ vs. $\mathrm{Nb} / \mathrm{Y}$ plot (figure 6). 

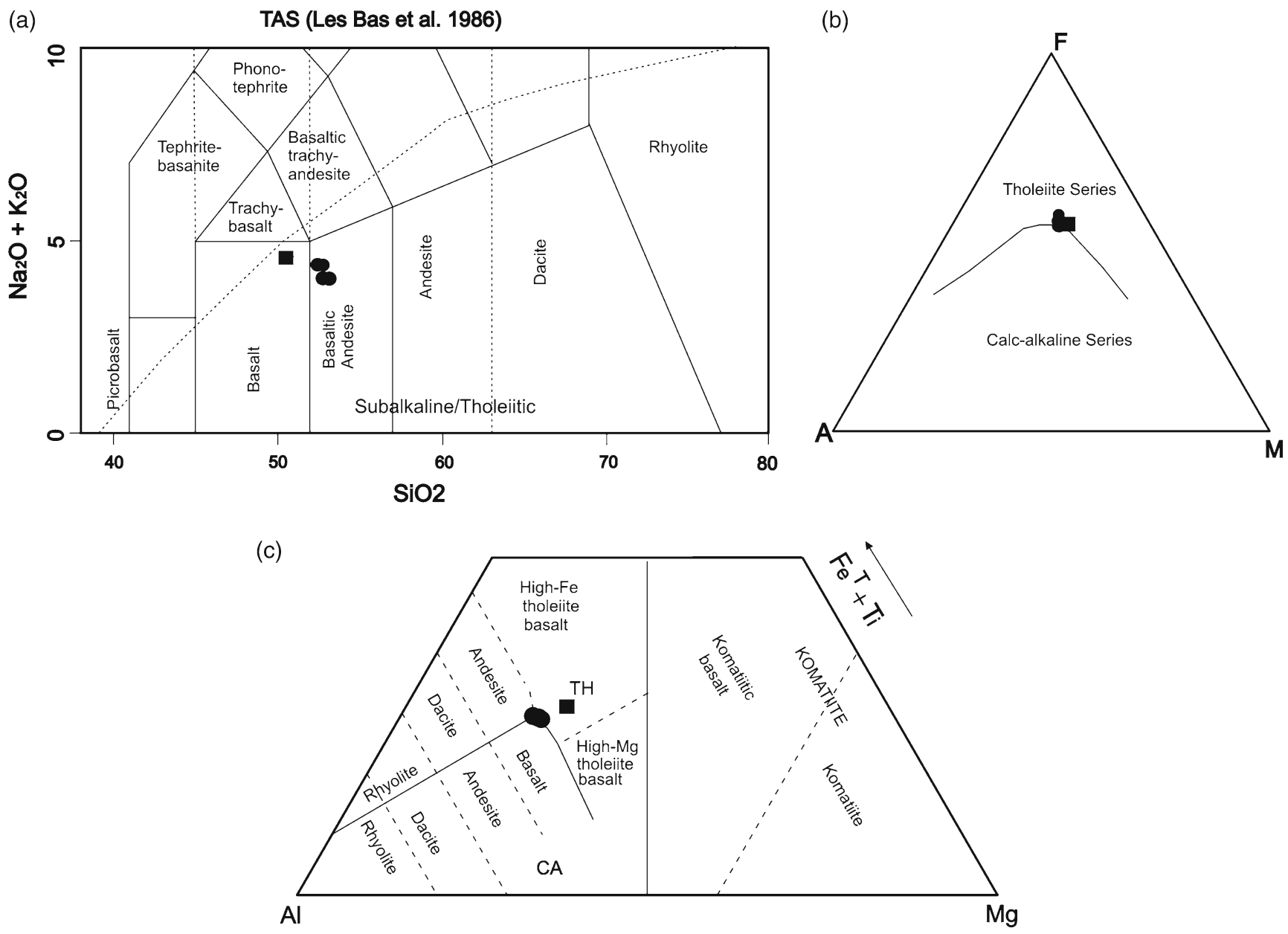

Figure 5. Major element classification shows (a) basaltic-to-basalt andesitic composition in TAS diagram, (b) marginally tholeiitic in AFM diagram of Irvine and Baragar (1971), and (c) while basalt-alkali basalt to tholeiitic in the plot of Jensen (1976). Solid circles represent Bandimal unit and solid square represents Pankipalli unit.

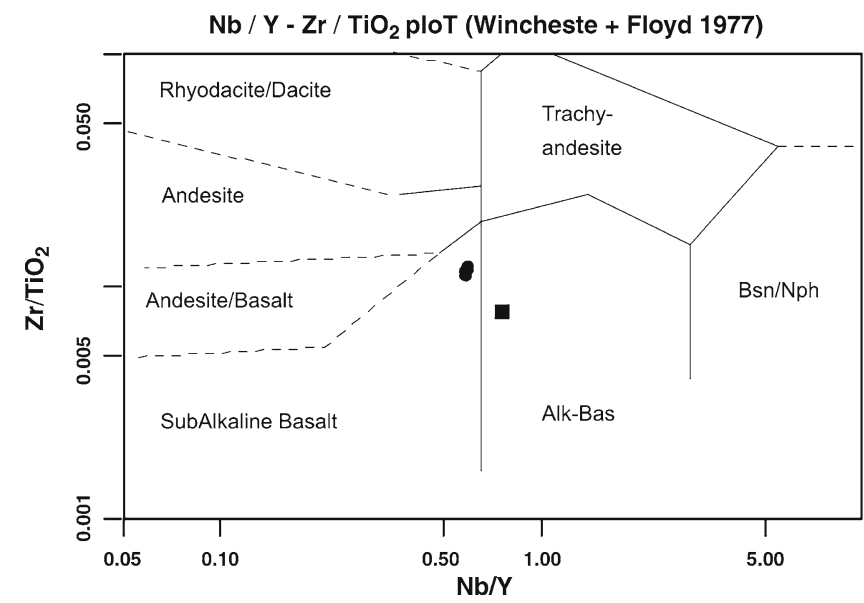

Figure 6. Some trace vs. major element plots show the subalkaline basalt in character $\left(\mathrm{Nb} / \mathrm{Y}\right.$ vs. $\mathrm{Zr} / \mathrm{TiO}_{2}$ plot).

The trace element data show overall enrichment (one to two orders) with respect to the composition of primitive mantle. Multi-trace element diagram indicates characteristic enrichment of large ion lithophile elements (LILE) such as $\mathrm{Sr}, \mathrm{K}, \mathrm{Rb}$,
Ba and Th, in comparison with high field strength elements (HFSE) such as Nb, P, Zr, Ti, and Y. A definite enrichment of $\mathrm{Pb}$ and $\mathrm{Ba}$ with slight depletion of $\mathrm{Nb}$ and $\mathrm{P}$ are characteristic of this rock (figure 7a). Some of the incompatible trace element ratios (LILE/HFSE and LILE/REE) have been calculated in table 3 and are compared with the reported average values of crust and mantle (Hoffmann 1988). The ratios like $\mathrm{Nb} / \mathrm{Th}$ and $\mathrm{Nb} /$ La are of particular importance due to the relative immobility of these elements and their ability to test the degree of crustal contamination during the passage through sialic crust enriched in Th and LREE. These ratios are in the range of 0.56-0.75 for $\mathrm{Nb} / \mathrm{La}$ and 2.9-3.4 for $\mathrm{Nb} / \mathrm{Th}$, and these values fall in between the average crustal and mantle values. Chondrite-normalized REE plot (figure 7b) shows overall enrichment of LREE in contrast to HREE $\left[(\mathrm{La} / \mathrm{Yb})_{\mathrm{N}}=6.45-8.64\right]$. In the LREEs, slope is moderate, i.e., $(\mathrm{La} / \mathrm{Sm})_{\mathrm{N}}=$ 2.30-2.97 which is similar in the HREE spectrum $\left[(\mathrm{Eu} / \mathrm{Yb})_{\mathrm{N}}=2.56-2.65\right]$. The pattern is almost devoid of any $\mathrm{Eu}$ anomaly $\left(\mathrm{Eu} / \mathrm{Eu}^{*}=1.0-1.04\right)$. 
(a)

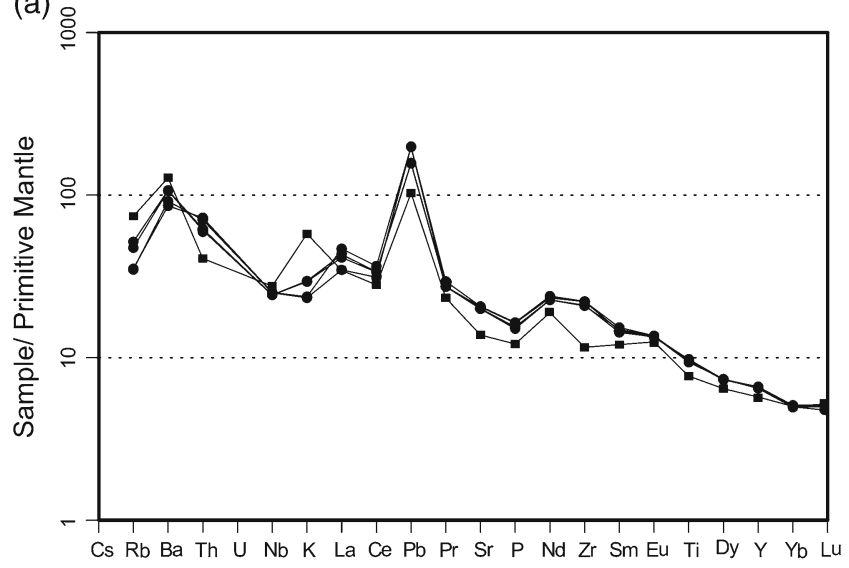

(b)

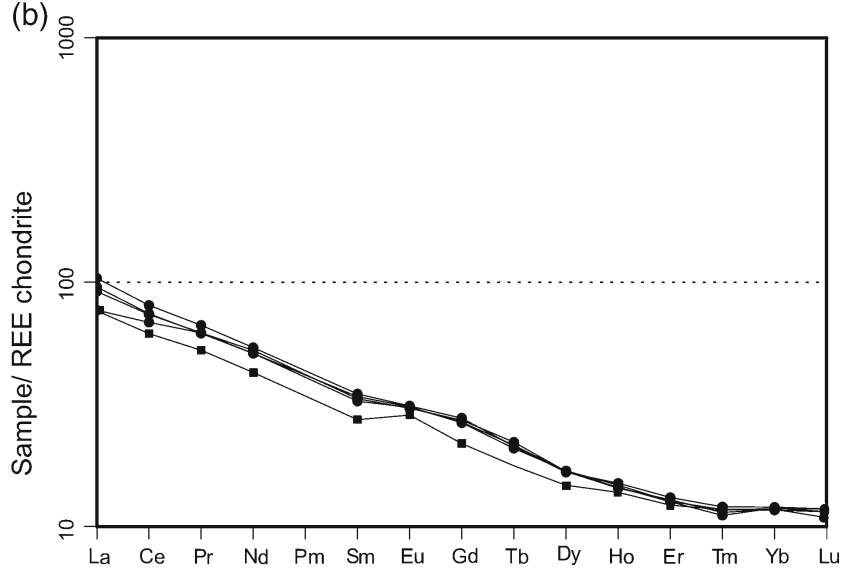

Figure 7. (a) Chondrite-normalized multiple trace element pattern. Note the enrichment of $\mathrm{Pb}$ and $\mathrm{Ba}$ and slight depletion of $\mathrm{Nb}$ and $\mathrm{P}$ in both the plots. (b) Chondritenormalized rare earth element pattern showing LREEenriched character.

The results of whole rock $\mathrm{Rb}-\mathrm{Sr}$ and $\mathrm{Sm}-\mathrm{Nd}$ isotope analyses are listed in table 4 . The initial $\mathrm{Nd}$ value is in the range of $0.510815-0.510919$ and initial $\mathrm{Sr}$ is in the range of 0.709377-0.706672. The epsilon $(\varepsilon)$ values are a measure of the deviations of the isotopic ratios in the samples from the expected value in a uniform reservoir. The $\varepsilon$ values for both $\mathrm{Sr}$ and $\mathrm{Nd}$ isotopes have been calculated, as these values can be used to test the cogenetic character and contamination in the samples, or can be a measure of the extent to which the magmas, when they cooled to form the rocks, had fractionated relative to their postulated depleted mantle source(s). The calculated $\varepsilon$ values are $\varepsilon^{t} \mathrm{Nd}=+(0.3-2.3)$ and $\varepsilon^{t} \mathrm{Sr}=+(54.56-92.91)$, where $t=1421$ Ma. In $\varepsilon^{t} \mathrm{Nd}$ vs. $\varepsilon^{t} \mathrm{Sr}$ isotope correlation diagram (figure 8) the studied samples plot in the field of positive $\varepsilon^{t} \mathrm{Nd}$ and positive $\varepsilon^{t} \mathrm{Sr}$. The $T_{\mathrm{DM}}$ ages refers to the depleted mantle model ages calculated from the $\mathrm{Nd}$ isotope ratios, and is a measure of the length of time of the sample has been separated from the mantle from which it was originally
Table 3. Selected incompatible trace element ratio for diabasic rock of Bandimal. The average crust and mantle values are given from Hoffmann (1988).

\begin{tabular}{lccccc}
\hline & $\mathrm{Th} / \mathrm{La}$ & $\mathrm{Nb} / \mathrm{La}$ & $\mathrm{Nb} / \mathrm{Th}$ & $\mathrm{Ba} / \mathrm{Nb}$ & $\mathrm{Ce} / \mathrm{Pb}$ \\
\hline 10/L7 & 0.19 & 0.56 & 2.9 & 33.5 & 4.6 \\
$7 / 21$ & 0.18 & 0.59 & 3.3 & 43.1 & 5.4 \\
10/L7b & 0.25 & 0.75 & 3 & 35.9 & 3.9 \\
$7 / 21 \_2$ & 0.18 & 0.61 & 3.4 & 42.9 & 5.4 \\
$7 / 25$ & 0.16 & 0.81 & 5.6 & 45.5 & 6.8 \\
Mantle & 0.13 & 1 & 8 & 10 & 9 \\
Crust & 0.22 & 0.7 & 3 & 22 & 4 \\
\hline
\end{tabular}

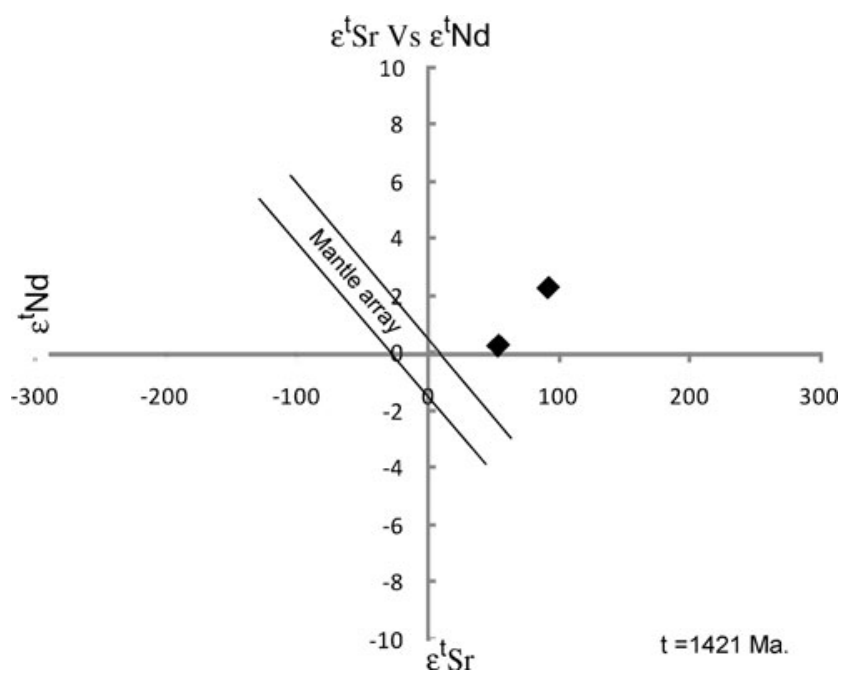

Figure 8. $\varepsilon \mathrm{Sr}$ vs. $\varepsilon \mathrm{Nd}$ plot. The values are calculated at $t=1421 \mathrm{Ma}$. Note the positive displacement away from the mantle values and the whole rock samples plot in the upper right quadrant as both $\varepsilon \mathrm{Sr}$ and $\varepsilon \mathrm{Nd}$ are positive. This can be due to the contamination of basaltic magma by crustal components that had high $\mathrm{Sr}$ abundances yielding $R$ values $>1$, where $R=(\mathrm{Sr} / \mathrm{Nd})_{\text {basalt }} /(\mathrm{Sr} / \mathrm{Nd})_{\text {contaminant }}$ (DePaolo and Wasserburg 1979). The arkosic sediments rich in feldspars could have been the potential contaminant that increased the $\varepsilon$ Sr much more rapidly relative to decreasing the $\varepsilon \mathrm{Nd}$ values in the magmas parental to the diabasic intrusive rock.

derived. The calculated depleted mantle model age for this intrusive is 1.7-1.9 Ga.

The positive $\varepsilon$ values of $\mathrm{Nd}_{(t)}$ and $\mathrm{Sr}_{(t)}$ imply that this rock have greater ${ }^{143} \mathrm{Nd} /{ }^{144} \mathrm{Nd}$ and ${ }^{87} \mathrm{Sr} /{ }^{86} \mathrm{Sr}$ ratios than those in the depleted mantle source of the magma from which it is derived. Using the $\mathrm{Sr}, \mathrm{Rb}, \mathrm{K}, \mathrm{Pb}$, abundance, ratios of $\mathrm{Th} / \mathrm{La}$ (0.18-0.25), Nb/La (0.56-0.75), Nb/Th (2.9-3.4), $\mathrm{Ba} / \mathrm{Nb}(33.5-43.1)$ and $\mathrm{Ce} / \mathrm{Pb}(3.9-5.4)$ (table 3) in the studied rocks and high ${ }^{87} \mathrm{Sr} /{ }^{86} \mathrm{Sr}$ ratio partial assimilation of continental crust or sedimentary material within the magma is interpreted. It may reflect derivation of these magmas from incompatible element enriched regions of the subcontinental mantle. 


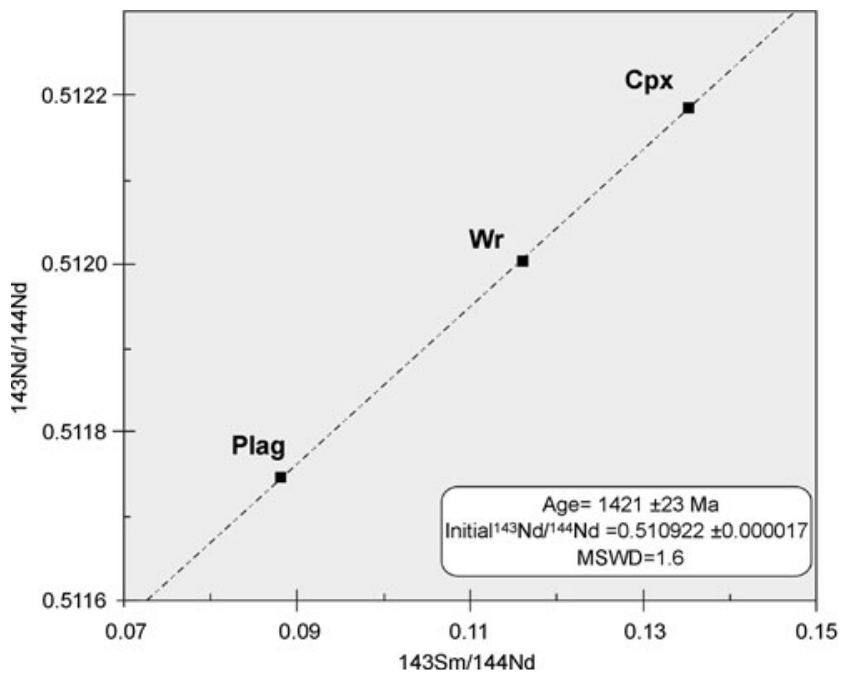

Figure 9. Whole rock-mineral $\mathrm{Sm}-\mathrm{Nd}$ isochron plot yielding an age of $1421 \pm 23 \mathrm{Ma}(\mathrm{MSWD}=1.6)$ which is interpreted as the emplacement age of the diabasic intrusive.

\section{Geochronology}

Fresh rock samples are collected from the central part of the intrusive body which have been analyzed for $\mathrm{Rb}-\mathrm{Sr}$ and $\mathrm{Sm}-\mathrm{Nd}$ isotopic composition. The data are presented in table 4 . Whole rock powder sample was used for both $\mathrm{Rb}-\mathrm{Sr}$ and $\mathrm{Sm}-\mathrm{Nd}$ analyses, whereas fresh mineral grains of pyroxene and feldspar have been separated for Sm-Nd isotopic analysis. The powdered sample of 120 mesh size is taken for heavy-mineral separation process using bromoform (specific gravity 2.89 at $20^{\circ} \mathrm{C}$ ). Both the heavy and lighter fractions are separated using Frantz ${ }^{\circledR}$ Isodynamic Magnetic Separator (Model LB-1). Finally the mineral grains are hand-picked under binocular microscope.

Sm-Nd mineral and whole rock data define a linear array with reasonable spread in ${ }^{147} \mathrm{Sm} /{ }^{144} \mathrm{Nd}$ ratios yielding an isochron (figure 9) which corresponds to an age of $1421 \pm 23$ Ma $(2 \sigma$, $\mathrm{MSWD}=1.6)$ with an initial ${ }^{143} \mathrm{Nd} /{ }^{144} \mathrm{Nd}=$ $0.510922 \pm 0.000017(2 \sigma)$. As the rock is megascopically and petrographically least altered and unmetamorphosed, we consider this age as the emplacement age of the intrusive. Hence, considering the discordant relationship of the studied intrusive with the Saraipalli strata, an age older than ca. $1420 \mathrm{Ma}$ is proposed for the Saraipalli Formation of Singhora Group.

\section{Discussion}

Going beyond the conventional approach of studying basic dykes within Proterozoic sedimentary basins with the goal of (i) age bracketing of 


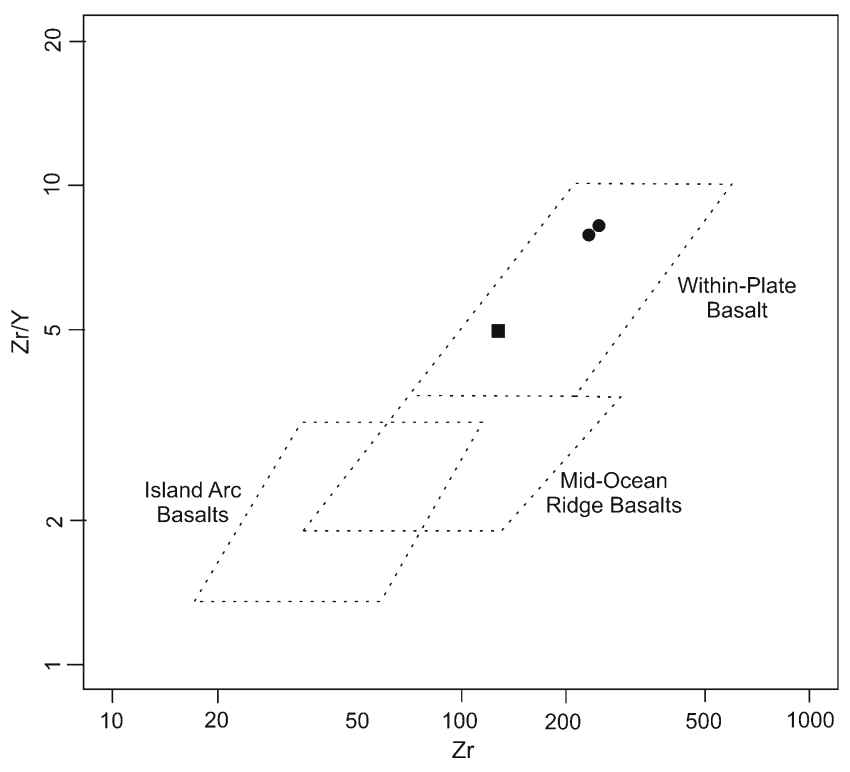

Figure 10. Tectonic discrimination diagram using immobile trace elements $\mathrm{Zr}$ and $\mathrm{Y}$ shows an affinity towards withinplate basalt.

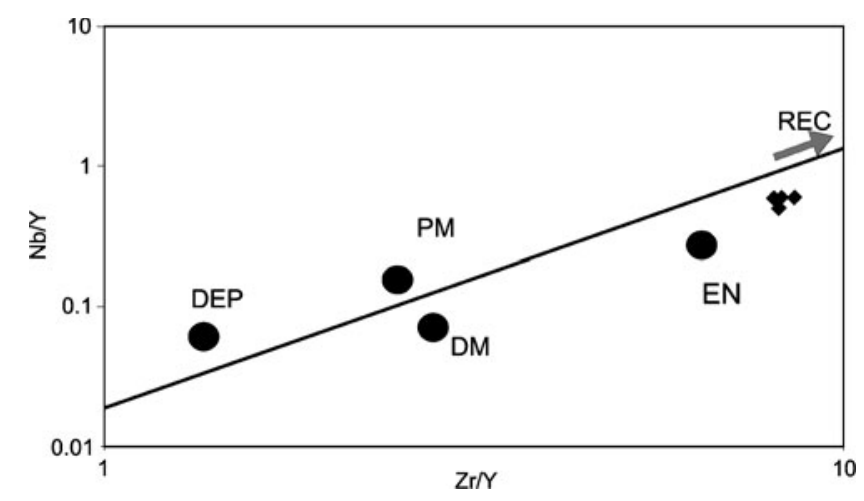

Figure 11. Diagram showing mantle composition components and fields for basalts of different tectonic settings. The diagram is after Condie (2005). $\downarrow$ : studied samples, EN: enriched component, PM: primitive mantle, REC: recycled component, DM: shallow depleted mantle, DEP: deep depleted mantle. Note the non-plume recycled magma is the source character for the studied intrusive.

the host basin, and (ii) geochemical characterization of mantle source and crust-mantle interaction, studies on concordant and discordant lithodemic units have become further sought after in recent times as dykes, particularly when in the form of fanning swarm, are correlated with crustalscale extensional events leading to the break-up of continents (Goldberg 2010). In this backdrop, study of present intrusive unit is felt necessary as it is hosted within Mesoproterozoic Singhora basin, the time frame through which supercontinent 'Columbia' witnessed its final fragmentation
(Li et al 2008; Yakubchuk 2010). Besides addressing these global issues, such study is also necessary to understand evolution and correlation between laterally adjacent sedimentary basins on the eastern part of the Bastar craton of India, and to unravel the relationship of the basins, if any, with regional tectonic grains involving different crustal provinces, viz., the craton and adjacent orogenic hinterland, i.e., EGB.

The studied discordant intrusive though unmetamorphosed, yet preserves evidences of minor hydrothermal alteration. Compositionally, the intrusive is basalt-to-subalkaline andesitic tholeiite (hypersthene and quartz normative meta-aluminous basalt). Subophitic texture is represented by partially sericitized plagioclase laths and augite, the dominant pyroxene species. $\mathrm{Fe}-\mathrm{Ti}$ oxides are recalculated to solid solution of ilmenite and hematite. Primitive mantle-normalized trace element data shows overall enriched character. LIL elements are one order more enriched. Enrichment of $\mathrm{Pb}$ and slight depletion of $\mathrm{Nb}$ and $\mathrm{P}$ is characteristic. The intrusive shows a prominent affinity towards within-plate basalt at $\mathrm{Zr} / \mathrm{Y}$ vs. Zr plot (figure 10) with strong evidence in favour of nonplume-recycled magma as a possible source (Nb/Y vs. Zr/Y plot, Condie 2005) (figure 11). Some selective trace element ratios (Th/La, $\mathrm{Nb} / \mathrm{La}, \mathrm{Nb} / \mathrm{Th}, \mathrm{Ba} / \mathrm{Nb}$ and $\mathrm{Ce} / \mathrm{Pb}$ ) are compared with the average crustal and mantle values (Hoffmann 1988). The HFSE elements which are less immobile, e.g., $\mathrm{Nb}$, Th and La have their ratios closer to the average crustal values (table 3 ). The incompatible-element enriched basalts have ratios of several strongly incompatible trace elements, including $\mathrm{Nb} / \mathrm{U}$ and $\mathrm{Ce} / \mathrm{Pb}$ ratios close to those of the continental crust suggesting that crustal component played a role in the genesis of the intrusive. Our data have been compared with the available data of plume-related basalts for different other HFS elemental ratios (e.g., $\mathrm{Ce} / \mathrm{Pb}, \mathrm{Nb} / \mathrm{La}, \mathrm{Ba} / \mathrm{La})$. It has been observed that our data is plotted far away from plume-related rocks. Instead, they have an affinity towards the field of sediment mixing or continental crustal assimilation. In the $\varepsilon \mathrm{Sr}$ vs. $\varepsilon \mathrm{Nd}$ diagram (figure 8) the whole rock samples plot in the upper right quadrant as both $\varepsilon \mathrm{Sr}$ and $\varepsilon \mathrm{Nd}$ are positive. When different extents of mixing between two components take place it results in an array of points defining hyperbolae in the $\varepsilon \mathrm{Sr} v s . \varepsilon \mathrm{Nd}$ diagram. The shape of the hyperbolic curve will depend on the ratio of $\mathrm{Sr} / \mathrm{Nd}$ values of the two components, $R$, where $R=(\mathrm{Sr} / \mathrm{Nd})_{\text {basalt }} /(\mathrm{Sr} / \mathrm{Nd})_{\text {contaminant }}$ (DePaolo and Wasserburg 1979). If $R<1$, the mixing curve will be concave; $>1$ it will be convex and $=1$ will yield a straight line. The plot of the samples in figure 8 can be due to the contamination 
of basaltic magma by crustal components that had high Sr abundances. The arkosic sediments rich in feldspars could have been the potential contaminant that increased the $\varepsilon$ Sr much more rapidly relative to decreasing the $\varepsilon \mathrm{Nd}$ values in the magmas parental to the diabasic intrusive rock. However, more samples are required to quantify the extent of mixing. Hence, the studied diabasic intrusive of within-plate affinity preserves an indication of non-plume source with significant recycled components (selected HFSE elemental ratio) and crustal contamination before its final emplacement. LREE enrichment $\left[(\mathrm{La} / \mathrm{Yb})_{\mathrm{N}}=6.45-8.64\right]$ in chondritenormalized REE plot without any perceptible $\mathrm{Eu}$ spike is suggestive of highly fractionated melt that has undergone crustal contamination processes. Positive $\varepsilon N d$ value also indicates the depleted nature of the protolith. Three-point (Sm-Nd whole rock, mineral separates) isochron yields an emplacement age of $1421 \pm 23$ Ma. It is noteworthy that the timing of intrusive emplacement is synchronous with the mafic and felsic magmatism reported from Eastern Ghats granulite belt (1455 $\pm 80 \mathrm{Ma}$ and $1464 \pm 63 \mathrm{Ma}$; Shaw et al 1997), emplacement of alkaline complexes at the western boundary ( $\sim 1.4$ to $1.5 \mathrm{Ga}$, Upadhyay et al 2009), emplacement of large-scale basic igneous intrusion (represented by metagabbro) within the southern granulite belt of Sausar mobile belt (Roy et al 2006), development of terrain boundary shear zone on the southeastern part of Singhora basin and the magmatic intrusions in Bastar craton in and around the terrain-boundary shear zone on the east of Khariar basin (Biswal et al 2003; Ratre et al 2010). It may be pertinent to mention here that the initiation of Khariar basin is nearly coeval with that of the Singhora basin as indicated by the age of porcellanitic tuff layer present at a comparable stratigraphic level towards the basal parts of both the basin successions (1450-1500 Ma, Das et al 2009). Together all the signatures suggest a major tectono-thermal event around $1400 \mathrm{Ma}$ that affected eastern Indian subcontinent involving its different crustal domains, viz., the deep crustal granulites (a probable fold-thrust belt), the craton and craton-hosted sedimentary basins. Recent discovery of ca. $1.33 \mathrm{Ga}$ U-Pb zircon age of the Kanigiri ophiolite mélange is significant as it implies an arc-continent collision at the cratonmobile belt contact (Dharma Rao et al 2010). Collating all these signatures it seems that similar collisional tectonism was operative all along the boundary of EGB and Bastar craton in the time period between $\sim 1.3$ and 1.5 Ga. Moreover, in terms of Proterozoic 'Supercontinent' framework this time frame coincides with the last phase of growth of the supercontinent "Columbia". Though during this time some continental blocks of this supercontinent experienced initiation of break-up, the East Indian cratonic part on the other hand, was still going through a phase of collisional tectonic build-up.

Working on the tholeiite and boninite-norite rocks exposed in different parts of Bastar craton in the form of volcanics and dykes; Srivastava and Singh (2004), Srivastava and Gautam (2009) and Srivastava (2006) proposed rifting in the Mesoproterozoic time. Roy et al (2006) related the rifting in the southern Bastar craton with basic magmatism within the southern granulites of Sausar mobile belt. Patranabis-Deb and Chaudhuri (2007) surmised initiation and evolution of Chhattisgarh basin in a rift related set-up. Such craton-scale rift system is commonly tagged with a major crustalscale extension or potential continental break-up event associated with plume activity (Meert 2002; Goldberg 2010). However, the non-plume character of the studied intrusive, does not fall in this category. On the contrary, the geographic orientation of the intrusive is parallel to the orientations of:

- shear zone at the south of Singhora basin and

- lateral ramp of proposed thrust-ramp structure of Eastern Ghats Belt (Biswal et al 2003).

Also, the Saraipalli Formation with which the intrusive shows discordant relationship and the Bhalukona Formation that immediately overlies it - both show plenty compressional features in the form of folds ranging from outcrop to regional scale. Hence, considering the field relationships and geochemical character of the intrusive we are inclined to relate the opening up of the fracture system through which emplacement of intrusive took place ca. $1421 \mathrm{Ma}$ with oblique compression, i.e., NW-SE compression on the so far deposited Singhora sediments.

\section{Acknowledgements}

This work forms part of the Ph.D. thesis of PD who thanks Department of Science and Technology (DST) for providing fellowship during this work. This work is done as a part of a research project funded by the Department of Science and Technology, Govt. of India. We are thankful to Dr R K Srivastava and an anonymous reviewer for their critical comments on our manuscript. We would like to thank Ashish Sarkar of Pandit Deen Dayal Institute of Petroleum Technology, Gandhinagar for many fruitful discussions. The authors thank Sankar Bose of Presidency College, Kolkata for the help during microphotographic and EPMA analysis. 


\section{References}

Anand R and Balakrishnan S $2010 \mathrm{~Pb}$, Sr and Nd isotope systematics of metavolcanic rocks of the Hutti greenstone belt, Eastern Dharwar craton: Constraints on age, duration of volcanism and evolution of mantle sources during Late Archean; J. Asian Earth Sci. 39 1-11.

Biswal T K, Sinha S, Mandal A, Ahuja H and Das M K 2003 Deformation pattern of Bastar craton adjoining Eastern Ghat mobile belt, NW Orissa; Gond. Geol. Mag. Spec. Publ. 7 101-108.

Bose P K, Sarkar S, Mukhopadhyay S, Saha B and Eriksson P 2008 Precambrian basin-margin fan deposits: Mesoproterozoic Bagalkot Group, India; Precamb. Res. 162 264-283.

Condie K C 2005 High field strength element ratio in Archean basalts: A window to evolving source of mantle plumes?; Lithos 79 491-504.

Chakraborty P P, Sarkar A, Das K and Das P 2009 Alluvial fan to storm-dominated shelf transition in the Mesoproterozoic Singhora Group, Chattisgarh Supergroup, Central India; Precamb. Res. 170 88-106.

Chakraborty P P, Dey S and Mohanty S 2010 Proterozoic platform sequences of Peninsular India: Implications towards basin evolutions and supercontinent assembly; J. Asian Earth Sci. 39 589-607.

Dalziel I W D 1991 Pacific margins of Laurentia and East Antarctica-Australia as a conjugate rift pair: Evidence and implications for an Eocambrian supercontinent; Geology 19 598-601.

Das N, Dutta D R and Das D P 2001 Proterozoic cover sediments of southeastern Chattisgarh state and adjoining parts of Orissa; Geol. Surv. India Spec. Publ. 55 237-262.

Das D P, Kundu A, Das N, Dutta D R, Kumaran K, Ramamurthy S, Thangavelu C and Rajaiya V 1992 Lithostratigraphy and sedimentation of Chattisgarh basin; Indian Min. 46 271-288.

Das K, Yokoyama K, Chakraborty P P and Sarkar A 2009 Basal tuff contemporaneity of Chattisgarh and Khariar basins, based on new dates and geochemistry; J. Geol. $11788-102$.

DePaolo D J and Wasserburg G J 1979 Petrogenetic mixing models and Nd-Sr isotopic pattern; Geochim. Cosmochim. Acta 43 615-627.

Dharma Rao C V, Santosh M and Wu Y B 2010 Mesoproterozoic ophiolitic mélange from the SE periphery of the Indian plate: $\mathrm{U}-\mathrm{Pb}$ zircon ages and tectonic implications; Gond. Res., doi:10.1016/j.gr.2010.06.007.

French J E, Heaman L M, Thomas C and Srivastava R K 2008 1891-1883 Ma Southern Bastar-Cuddapah mafic igneous events, India: A newly recognized large igneous province; Precamb. Res. 160 308-322.

Goldberg A S 2010 Dyke swarms as indicators of major extensional events in the 1.9-1.2 Ga Columbia supercontinent; J. Geodynamics 50 176-190.

Hoffman P F, Kaufman A J, Halverson G P and Schrag D P 1998 A Neoproterozoic snowball Earth; Science 281 1342-1346.

Hoffmann A W 1988 Chemical differentiation of the Earth: The relationship between mantle, continental crust and oceanic crust; Earth Planet. Sci. Lett. 90 $297-314$.

Irvine T N and Baragar W R A 1971 A guide to the chemical classification of the common rocks; Canadian J. Earth Sci. 8 523-548.

Jacobsen S T B and Wasserburg G J 1980 Sm-Nd isotopic evolution of chondrites; Earth Planet. Sci. Lett. 50 $139-155$.
Jensen L S 1976 A new cation plot for classifying subalkalic volcanic rocks; Ontario Division of Mines, Miscellaneous Paper 6621.

Karmakar S, Bose S, Das K and Dasgupta S 2009 Proterozoic Eastern Ghats Belt, India - A witness of multiple orogenies and its lineage with ancient supercontinents; $J$. Virtual Explorer 32, paper 3.

Le Bas M J, Rex D C and Stillman C J 1986 The Early magmatic chronology of Fuerteventura, Canary Islands; Geol. Mag. 123 287-298.

Li Z X, Bogdanova S V, Collins A S, Davidson A, DeWaele B, Ernst R E, Fitzsimons I C W, Fuck R A, Gladkochub D P, Jacobs J, Karlstrom K E, Lu S, Natapov L M, Pease V, Pisarevsky S A, Thrane K and Vernikovsky V 2008 Assembly, configuration, and breakup history of Rodinia: A synthesis; Precamb. Res. 160 179-210.

Liew T C and Hoffmann A W 1988 Precambrian crustal components, plutonic associations, plate environment of the Hercynian Fold Belt of central Europe: Indications from a Nd and Sr isotopic study; Contrib. Mineral. Petrol. 88 129-138.

Ludwig K R 2003 User's Manual for Isoplot 3.00: A Geochronological toolkit for Microsoft Excel; Berkeley Geochronology Centre Spec. Publ. 470.

Meert J G 2002 Paleomagnetic evince for a paleoMesoproterozoic supercontinent Columbia; Gond. Res. 5 $207-215$.

Murti K S 1987 Stratigraphy and sedimentation in Chattisgarh basin; In: Purana basins of Peninsular India (ed.) Radhakrishna B P, Geol. Soc. India Memoir 6 239-257.

Moores E M 1991 Southwest US-East Antarctic (SWEAT) connection: A hypothesis; Geology 19 425-428.

Patranabis-Deb S, Bickford M E, Hill B, Chaudhuri A K and Basu A 2007 SHRIMP ages of Zircon in the uppermost tuff in Chattisgarh Basin in central India require 500-Ma adjustment in Indian Proterozoic stratigraphy; J. Geol. 115 407-415.

Patranabis-Deb S and Chaudhuri A K 2007 A retreating fan-delta system in the Neoproterozoic Chhattisgarh rift basin; central India: Major controls on its evolution; AAPG Bull. 91 785-808.

Pearce J A and Norry M J 1979 Petrogenetic implication of $\mathrm{Ti}, \mathrm{Zr}, \mathrm{Y}$ and $\mathrm{Nb}$ variations in volcanic rocks; Contrib. Mineral. Petrol. 69 33-47.

Ratre K, De Waele B, Biswal T K and Sinha S 2010 SHRIMP geochronology for the 1450 Ma Lakhna dyke swarm: Its implication for the presence of Eoarchaean crust in the Bastar craton and 1450-517 Ma depositional age for Purana Basin (Khariar), Eastern Indian Peninsula; 6th International Dyke Conference Abstract, vol. 126.

Rogers J J W and Santosh M 2002 Configuration of Columbia, a Mesoproterozoic supercontinent; Gond. Res. 5 5-22.

Roy A, Kagami H, Yoshida M, Roy A, Bandopadhyay B K, Chattopadhyay A, Khan A K, Huin A K and Pal T 2006 $\mathrm{Rb}-\mathrm{Sr}$ and $\mathrm{Sm}-\mathrm{Nd}$ dating of different metamorphic events from the Sausar mobile belt, central India: Implications for Proterozoic crustal evolution; J. Asian Earth Sci. 26 61-76.

Sarkar A, Nanda J K, Panda P K, Patra P C, Bishui P K and Gupta S N 1994 Rairakhol alkaline complex, Orissa sector, Eastern Ghats belt: A Rb-Sr isotopic study; Ext. abst., Workshop on Eastern Ghats Mobile Belt, Visakhapatnam, pp. 75-76.

Sarkar G, Corfu F, Paul D K, Mcnaughton N J, Gupta S N and Bishui P K 1993 Early Archaean crust in Bastar craton, central India - A geochemical and isotopic study; Precamb. Res. 62 127-137. 
Srivastava R K and Singh R K 2004 Trace element geochemistry and genesis of Precambrian sub-alkaline mafic dikes from the central Indian craton: Evidence for mantle metasomatism; J. Asian Earth Sci. 23 373-389.

Srivastava R K 2006 Geochemistry and petrogenesis of Neoarchaean high-Mg low-Ti mafic igneous rocks in an intracratonic setting, Central India craton: Evidence for boninite magmatism; Geochem. J. 40 15-31.

Srivastava R K and Gautam G C 2009 Precambrian mafic magmatism in the Bastar Craton, central India; J. Geol. Soc. India 73 52-72.

Shaw R K, Arima M, Kagami H, Fanning C M, Shairashi K and Motoyashi Y 1997 Proterozoic events in the Eastern Ghats granulite belt, India: Evidence from Rb-Sr, Sm-Nd systematics and SHRIMP dating; J. Geol. 105 645-658.

Upadhyay D, Gerdes A and Raith M M 2009 Unraveling sedimentary provenance and tectonothermal history of high temperature metapelites using zircon and monazite chemistry: A case study from the Eastern Ghats Belt, India; J. Geol. 117 665-683.

Winchester J A and Floyd P A 1977 Geochemical discrimination of different magma series and there differentiation products using immobile elements; Chem. Geol. 20 325-345.

Windley Brian F 1995 Uniformitarianism today: Plate tectonics is the key to the past; Geol. Soc. London Memoirs 16 11-23.

Yakubchuk A 2010 Restoring the supercontinent Columbia and tracing its fragments after its breakup: A new configuration and a Super-Horde hypothesis; J. Geodyn. 50 166-175.

Zhao G, Sun M, Wilde S A and Li S 2004 A PaleoMesoproterozoic supercontinent: Assembly, growth and breakup; J. Earth Sci. Rev. 67 91-123. 